Article

\title{
Church-State Separation and Challenging Issues Concerning Religion
}

\author{
Eric Vincent Batalla ${ }^{1}(\mathbb{D})$ and Rito Baring ${ }^{2, *(D)}$ \\ Political Science Department, De la Salle University, Manila 0922, Philippines; eric.batalla@dlsu.edu.ph \\ 2 Theology and Religious Education Department, De la Salle University, Manila, Manila 0922, Philippines \\ * Correspondence: rito.baring@dlsu.edu.ph
}

Received: 24 January 2019; Accepted: 11 March 2019; Published: 15 March 2019

\begin{abstract}
In its declaration of principles, the 1987 Philippine Constitution provides for the separation of Church and State. While the principle honors distinctions between temporal and spiritual functions, both Church and State maintain a unique and cooperative relationship geared towards the common good. However, traditional boundaries governing political and religious agency have been crossed during Duterte's presidency causing a conflict between leaders of government and the Catholic hierarchy. In the process, the conflict has resurfaced issues about the principle of Church-State separation. What accounts for the changing Church-State relations in the Philippines? How will this conflict affect State policy towards religion, religious freedom, and religious education? In the present study we discuss the present context of the Church-State separation principle in the Philippines. We argue that institutional relations between Church and State remain stable despite the Duterte-Catholic Church conflict.
\end{abstract}

Keywords: religion; religious freedom; separation of Church-State; Philippine church

\section{Introduction}

Until recently, church-state relations have been generally friendly in the Philippines. Although prominent Catholic leaders and members have been known to participate in historic political upheavals (e.g., People Power 1 in February 1986 and People Power 2 in January 2001) as well as in matters of public policy (e.g., Reproductive Health Law), the State has generally accorded respect for all religious institutions and has allowed religious plurality and diversity. State behavior toward religion and religious institutions is usually seen as the result of the observance of the constitutional principle of separation between church and state, which has been entrenched in the country since the past century.

However, recent altercations between the Philippine president and Catholic Church leaders have apparently blurred traditional secular and religious boundaries. The emergence of Rodrigo Duterte as a national political actor has ushered in a new period in government relations with the Catholic hierarchy. During the presidential campaign, Duterte entertained his audiences with populist jokes, including one where he cursed the Pope for creating a massive traffic jam in Manila during his visit. The controversial and offensive remarks did not endear Duterte to many Church leaders. A few days before election day, the Catholic Bishops Conference of the Philippines (CBCP) issued a pastoral letter encouraging Catholics not to vote for a candidate who is "morally reprehensible" and who has "scant regard for the rights of others and the teachings of the Church" (ABS-CBN News 2016). While waiting for his installation as Philippine president, Duterte began criticizing the Catholic Church for its hypocrisy, corruption, and political meddling (Manila Standard 2016, May 23). The incoming Chief Executive argued that because of their political meddling, Catholic leaders have violated the principle of separation of Church and State. The conflict between the presidency and the Catholic establishment had thus begun. 
For several reasons, the conflict is unique in the contemporary history of church-state relations in the Philippines. First, previous presidents, whether from the Catholic faith or not, have sought the blessings of the Catholic Church; Duterte did not, signaling the ascendancy of a new secular elite leader in the country. Second, for the first time a Philippine president has publicly cursed the Pope (even as a joke) and has openly challenged and criticized the Catholic Church and its teachings. Third, Catholic leaders have openly and repeatedly criticized the president on key public policy issues, especially his anti-drug war and attendant violations of human rights.

In observing how traditional boundaries governing political and religious agency have been crossed during Duterte's presidency, we ask: How can we account for this shift in Church-State relations? How will this conflict affect religious freedom and religious education?

The present study attempts to address these questions by examining historical, constitutional-legal, and political perspectives pertaining to Church-State relations in the Philippines. It begins with a brief survey of relevant theories on changing church-state relations, leading to a framework that underscores clashing interests and ideologies in order to shed light on the politics of religion. Then, we discuss the issue of "separation", noting constitutional and legal traditions of benevolent neutrality rather than interpretations of strict separation or neutrality. This legal setting nevertheless has not constrained state and religious actors from attacking each other. The article then proceeds with an analysis of clashing interests and ideologies and discuss its implications on the future of Church-State relations and their possible impact on religious freedom and education. Materials used for the study include news reports, relevant journal articles and books, Supreme Court decisions, and data obtained from websites of government agencies and Catholic affiliated organizations.

\section{Theoretical Perspectives}

A few theories have attempted to analyze changing patterns of church-state relations, or in general the relationship of religion, politics, and democracy. Modernization or secularization theory (Berger 1969; Inkeles and Smith 1976; Norris and Inglehart 2004; Pollack 2015) contends that religion's political role and importance declines through the process of modernization and economic development. Extreme variants of the theory even predict religion's demise. However, religious politics of the late 20th century and the persistence of religiosity and spirituality in many countries disprove the demise of religion argument. As Baring $(2018$, p. 1) argues, "Instead of losing its place in social life, religion resurfaces in unique articulations each time."

Based on case studies in the Philippines, Canceran (2016) observes the transformation of religion as secularism induced the decline of the authority and tradition of the institutional church represented by the ecclesiastical hierarchy. He argues, " ... religion is no longer controlled by organized religion but has been democratized through personal agency" (Canceran 2016, p. 128).

While modernization theory gives importance to structural changes in society to explain changing Church-State relations, rational choice theory emphasizes the role of interests and human agency, based on assumptions of decisionmakers as self-interested and utility-maximizing individuals. Particularly, Gill (2007, pp. 7-8) prescribes examining "the political and economic interests of politicians (rulers) as well as the institutional interests of religious leaders in the policy-making arena." A "thin" version of the theory is criticized for taking individual preferences as given and for understating the role of ideology in the making of state policies toward religion (Kuru 2009, p. 21).

Philpott (2007) and Kuru (2009) underscore the role of ideational factors (political theology and ideology). Philpott (2007) interest is in explaining the political pursuits of religious actors. He identifies two powerful influences, namely: differentiation (or the degree of autonomy between religious actors and states in their basic authority) and political theology (the set of ideas that religious actors hold about political authority and justice) (Philpott 2007, p. 505). Accordingly, Catholic political action (which led to democratization in countries like Poland and the Philippines) was based on the political theology adopted by the Second Vatican Council. The Council's political theology incorporated 
"human rights, religious freedom, democracy, and economic development" into Church teachings (Philpott 2007, p. 510).

Kuru (2009) proposes that two ideologies—assertive and passive secularism-explained variations in secular state policies toward religion. Accordingly, assertive secularism attempts to exclude religion from the public sphere and confine it to the private domain (Kuru 2009, p. 11). He cites the case of France as an example. Passive secularism on the other emphasizes state neutrality toward religion. This is observed in the case of the United States.

In explaining the changing pattern of church-state relations in the Philippines, it is difficult to single out any of the abovementioned theories. All have valid points that can be incorporated into a framework that applies to the local setting. Though criticized for its determinism, the structural approach, such as modernization theory, provides a context for agency action. However, it has been pointed out that modernization theory cannot fully explain political agency since individuals and institutions have different values and preferences.

Rational choice theory tends to remove ideational and non-material factors from the analysis. It also assumes that values and preferences are the same for a particular set of actors such as government leaders and members of the clergy. This assumption does not reflect the reality of differences in values and preferences of members of an institution. However, the theory cannot be easily dismissed since interests are an important variable to changes in public policy and church-state relations. Finally, ideational approaches often find difficulty in establishing causality and the links to political action (Lieberman 2002). Despite conceptual and methodological weaknesses in many works, an approach that recognizes the importance of ideas and ideology cannot be completely ignored; ideas and ideologies do matter in accounting for change.

In this study, we focus on the clash of interests and ideologies within a secularizing environment in order to clarify changing church-state relations in the Philippines. As such, the framework combines elements of structure, interests, and ideas (ideologies) in the analysis of change. The institutional interests of the Catholic Church fused with its theological doctrines guide its political action, which in turn, finds friction with rising secularism and government illiberalism. Changing church-state relations, or more precisely Catholic Church-State relationship, is demonstrated by two recent cases, to wit: the Reproductive Health legislation (Baring 2012) and the current Catholic church conflict with President Duterte.

\section{The Secular State and Church-State Separation}

The Philippines is a secular state that is friendly to religions. The secular state, according to Kuru (2009, p. 7), is defined by two main characteristics, namely: (1) the absence of institutional religious control of legislative and judicial processes, and (2) constitutionally mandated neutrality toward religions, and non-establishment of an official religion or atheism. Although a majority of the population is Catholic, the country is host to a variety of faiths (Baring 2011) with constitutional guarantees on the freedom of religion and the non-adoption of a State religion. This dispensation differs from other Southeast Asian countries like Burma, Malaysia and Thailand where religion is given a central role in national development (Von der Mehden 1986, p. 145).

The Philippines as a secular state is distinct from the one that prevailed during the Spanish colonial era (1570-1898). During Spanish rule, church and state in the Philippines enjoyed an unparalleled union. "Church influence was so strong, thinking became uniform, unorthodox ideas were condemned, and original scholarship was non-existent" (Aprieto 1981, p. 23). Church-state relations changed with the American occupation of the Philippines (1901-1946). The Americans established secular rule that strictly adhered to religious neutrality and toleration.

The American occupation has produced a strong ideological and institutional legacy for State-Church relations in postcolonial Philippines. Previous colonial laws and post-colonial constitutions had already established the secular tradition based on the first amendment of the United States Constitution. The 1987 Constitution reinforces this tradition to direct Church-State relations in 
the Philippines. Article III (The Bill of Rights), Section 5 of the 1987 Constitution provides that "no law shall be made respecting an establishment of religion or prohibiting the free exercise thereof. The free exercise and enjoyment of religious profession and worship, without discrimination or preference, shall forever be allowed. No religious test shall be required for the exercise of civil or political rights." (The Republic of the Philippines 1987). Religious neutrality is further provided by the constitutional provision that bars the use of public money or property to benefit or support any religious group (Article VI, Section 29).

The Philippine Constitution is more explicit than the American Constitution in its declaration of Church-State separation. In Article II (Declaration of Principles), Section 6, the Constitution states: "The separation of Church and State shall be inviolable." The application of this principle could be readily seen in the Omnibus Election Code, which disallows religious groups from registering as political parties, intervening in village-level elections, raising campaign funds, as well as coercing subordinates to vote for or against any candidate (Pangalangan 2015, p. 566).

The constitution nevertheless specifies religious accommodation in certain State affairs. First, the State allows the assignment of priests, preachers, ministers or dignitaries to "the armed forces, or to any penal institution, or government orphanage or leprosarium" (Article VI, Section 29.2). Second, it provides for tax exemption of religious institutions and their property "used for religious, charitable, or educational purposes" (Article VI, Section 28.3). Third, the State allows without additional cost to the government, optional religious instruction in public elementary and high schools, subject to the expressed written consent of parents and guardians and to the designation of instructors approved by religious authorities of the religion to which the children belonged (Article XIV, Section 3.3).

Jurisprudence further guides governmental actions with respect to the Church. In the United States, from where many Philippine legal doctrines are based, interpretations of Church-State relations vary, from "strictly separationist" (generally a hostile interpretation disallowing interaction in order to protect the State from the Church) and "strictly neutral" (not necessarily hostile but striving for a more secular state) to "benevolently neutral" (to protect the Church from the State). In the Philippines, a landmark ruling by the Supreme Court in 2003/2006 established that jurisprudence on Church-State relations is guided by benevolent neutrality (Estrada vs. Escritor 2003, 2006). In fact, the Supreme Court affirms that the Constitution is inspired and guided by this doctrine: "It is indubitable that benevolent neutrality-accommodation, whether mandatory or permissive, is the spirit, intent and framework underlying the Philippine Constitution" (Estrada vs. Escritor 2006). By benevolent neutrality, "the government must pursue its secular goals and interests but at the same time strives to uphold religious liberty to the greatest extent possible within flexible constitutional limits. Thus, although the morality contemplated by laws is secular, benevolent neutrality could allow for accommodation of morality based on religion, provided it does not offend compelling state interests." (Estrada vs. Escritor 2003).

In view of the above-cited constitutional provisions and jurisprudence, it could be said that the principle of Church-State separation in the Philippines does not strictly prevent the Church from engaging the State, and vice-versa. The observance of the principle should not be construed as a prohibition of state actors to act on public policies that might encroach upon certain religious beliefs nor should it be construed as a prohibition on religious organizations to shape public opinion and express their moral positions on executive policy and legislative issues. In this sense, Church-State political engagements are considered part of democratic processes subject to constitutional and legal constraints.

\section{Changing Church-State Relations}

Cooperative church-state relations have been demonstrated in various instances in the past. For instance, in the crafting of the 1987 constitution, members of the religious hierarchy were included in the constitutional commission, including two Catholic priests, a Catholic nun, a Protestant Minister and a member of the religious group, Opus Dei. In that commission, Joaquin Bernas, a Jesuit priest, prominently advocated for the principle of separation of Church and State (Buckley 2013, p. 204). The Church also engaged in numerous collaborations with the State in areas of political, social, 
economic, and human development. Such engagements include housing development projects, charity works for poverty alleviation, and mobilization of parish-based church members for honest and clean elections through the Parish Pastoral Council for Responsible Voting (PPCRV).

Of the various religious organizations in the Philippines, the Roman Catholic Church is among the oldest and most powerful. The Catholic Church wields enormous influence in the country's social and political affairs even if it does not have any formal role in secular governance (Pangalangan 2015, p. 568) nor has its influence been determinative of political and policy outcomes. From a pluralistic purview, the Catholic Church and its allied organizations could be seen as one of many interest groups that could influence public policy. However, it has also been considered as one of the major "extra-electoral strategic groups" during and after the Marcos regime that "can buttress or challenge the power of a president" (Thompson 2018, p.124). Indeed, the Catholic Church had figured prominently in the ousters of the late dictator, Ferdinand Marcos, through People Power 1 in February 1986 and of President Joseph Estrada in January 2001.

Yet by the mid-2000s, the political influence of the Catholic Church had begun to wane (Lagman 2017). Church leadership suffered with the death of Cardinal Jaime Sin in 2015. Sin was the key figure of the Catholic hierarchy instrumental to the rise of the Catholic Church as a strategic group that helped in the ouster of Presidents Marcos and Estrada.

After Cardinal Sin, Catholic political influence was tested by the reproductive health (RH) bill issue. For years since it was proposed in 1998, the Catholic Church had lobbied hard against the bill since the proposed legislation promoted the use of abortifacient contraception, which is contrary to Catholic beliefs about life. In contrast, $\mathrm{RH}$ advocates argued that the bill critically addresses many problems associated with poverty and overpopulation. Thus, the bill represented an ideological clash that involved religious doctrine and secular beliefs. Then, political interests came into play unexpectedly in July 2012. In his State of the Nation Address (SONA) in July 2012 (Official Gazette 2012), President Benigno Simeon Aquino III, who was favored by many Church leaders, suddenly pushed for the passage of the bill. During his presidential campaign, Aquino had promised support for the bill on reproductive rights. $\mathrm{RH}$ advocates therefore pressured Aquino to act on this promise. After his SONA, the president certified the bill as urgent in Congress.

During congressional deliberations, the Catholic Church came up with an organized national resistance to the proposed bill. RH proponents advanced "pro-choice" legal arguments while the Catholic Church advocated a "pro-life" moral stance (Baring 2012). Catholic leaders believed that they were protecting religious freedom rather than suppressing reproductive rights (Griffin 2015). It must be noted that many non-Catholic religious groups supported the bill. As it is, Catholics were also not united in their stand on the issue. For instance, professors from the Ateneo de Manila University issued a statement favoring the bill despite the University's formal rejection of that bill (Esmaquel 2012).

Mounting public tensions produced an impasse in Congress. In August 2012, House Speaker Feliciano Belmonte, a key Aquino ally and Liberal Party leader, suddenly moved to terminate the debates and prepared the House of Representatives for a vote. The vote stalled for lack of a quorum as Lower House legislators feared a political backlash. It was at this time that executive intervention stepped up. Apparently, without help from the executive branch, the bill would not have passed in Congress. Aquino, his budget secretary, Florencio Abad, and allies at the Liberal Party (LP) in Congress worked hard to persuade other legislators to vote for the bill. Since President Aquino already issued his commitment, it was in his interest as well as his allies' to see that the legislation succeeded. In late November 2012, the CBCP responded by issuing a statement urging Catholics not to vote for candidates who favored the bill (Pangalangan 2015, p. 568). This apparently bore little effect on the decision of many legislators. Eventually, in late December 2012, after much discord, the bill was passed into law.

A case was later filed at the Supreme Court questioning the constitutionality of the law. In Imbong vs. Ochoa (2014), the Supreme Court ruled on the constitutionality of the RH law but struck down certain provisions that violated the constitution's "no-abortion, non-coercion" principle. 
In deciding on the case, the court declared, "In conformity with the principle of separation of Church and State, one religious group cannot be allowed to impose its beliefs on the rest of the society. Philippine modem society leaves enough room for diversity and pluralism" (Imbong vs. Ochoa 2014).

The enactment of the RH bill signified a political setback for the Catholic Church. As Canceran (2016, p. 123) argued," In this RH debate, we are witnessing the decline of the power of the ecclesiastical authority and the traditional teachings of the church ... Society is no longer dominated by the singular authority and tradition of the Church but it has become diversified and fragmented by different forces and spheres competing for legitimacy."

The clash of ideologies and interests is also apparent in the antagonisms surrounding the Duterte-Catholic Church relations. Social justice and respect for life have been at the core of Catholic social doctrine. As such, the conduct of Duterte's anti-drug war, which has resulted in the extrajudicial killings of thousands of suspected drug peddlers and addicts, go against Catholic doctrine. Likewise, recent Church pronouncements regarding the inadmissibility of the death penalty directly opposes the Duterte government's proposal for the return of capital punishment. On the other hand, Duterte's populist ideology focuses on restoring social order (such as fighting drugs and criminality) and addressing other failures of the "liberal reformism" of previous administrations (Thompson 2016). However, violence and illiberalism, and perhaps even his irreverence toward Catholic authority, seem to form part of that populist ideology.

The recourse to forceful methods, to which many Filipinos silently agree given the inefficient criminal justice system (Batalla et al. 2018), is in the president's interests in order to fulfil his promise to deliver on his campaign against drugs, crime, and corruption. Thus, while the Catholic Church and President Duterte share certain common goals for the greater good, their approaches fundamentally differ. Duterte continues to maintain high public approval ratings amidst human rights criticisms from the Catholic establishment, foreign governments, and human rights organizations ((Alto Broadcasting System, Chronicle Broadcasting Network) ABS-CBN News 2019).

Over and above Duterte's verbal attacks and the Church's response, constitutional provisions guaranteeing religious freedom remain in place. The threats remain disturbing but have never altered the constitutional and legal boundaries between church and state. The Catholic Church as well as other religious institutions continue to participate in civil society in shaping public opinion (e.g., PPCRV) and expressing their moral positions in the political realm. However, the war of words may have set a precedent in government interactions with religious authority.

\section{Church-State Relations and Religious Education}

As earlier mentioned, the State allows optional religious instruction in public schools but subject to the written consent of the child's parent or guardian. Religious Education responds to social demands of lifelong learning through values formation, development of soft skills and conscientization. It is estimated that $87 \%$ of basic education students in the Philippines receive instruction from public schools while the private schools serve the remaining 12\% (Estrada 2017). Private schools are further classified into two general categories: faith-based and non-denominational basic education schools. Faith-based schools include schools categorized by different religious orientations: Islam, Iglesia ni Kristo, Protestants and Bible Christians, non-Christian sects, Buddhist and Hindu, and Catholic schools. Catholic schools only serve less than $12 \%$ of the basic student population.

The Catholic Educational Association of the Philippines (CEAP) identifies ethical religious views and religion for the total development of the human person as the core of the curriculum in basic education programs. With a membership of about 1400 Catholic affiliated schools operating throughout the country, the CEAP declares its commitment as mandated by its by-laws that Catholic education contributes towards social transformation and integral national development (CEAP 2014). Another Catholic organization, the Association of Catholic Universities of the Philippines (ACUP) aims to "contribute to social transformation by helping to seek and discover the root cause of contemporary problems" that impact on human life and relations among others (ACUP Primer, ACUP 1973). As 
such, it could be said that Philippine Catholic schools adhere to government policies that favor social and human development. Through character formation and conscientization, Religious Education lays the ground for Catholics to pursue collaboration with a critical mind. Responsible citizenship training (Lee et al. 2017) and soft skills development complement Religious Education's thrust to cultivate social and political awareness among Catholics as an essential dimension of religious commitment.

Since 2016, leaders of the Catholic Church and of Catholic universities have been at the forefront of criticizing the Duterte government's policies and policy proposals, such as anti-drug war and the proposed death penalty bill. Against the backdrop of this conflict with President Duterte, state policy toward religious freedom and religious education has not changed because of the pertinent constitutional guarantees. This has been tested recently when some Duterte supporters broached the idea of removing tax exemptions on Church properties and income, including those of religious educational institutions (Chanco 2016; Kapunan 2018).

At the House of Representatives, then Speaker Pantaleon Alvarez proposed in March 2017 that incomes of schools run by religious institutions be taxed (Cayabyab 2017). Schools run by the religious in the Philippines are non-stock, non-profit corporations that are exempted from taxes. Alvarez argued that the proposal was a government revenue-enhancing measure rather than a retaliation against the Catholic church and religious educational institutions critical of the administration. However, the proposal was met coldly even by government cabinet members and the Bureau of Internal Revenue who admonished him that this would go against the constitution. Facing stiff opposition to the proposal, Alvarez later opined that constitutional restrictions on taxing the Church shall be considered in a new federal constitution that the administration has been pushing (Inquirer.net 2018).

Reacting to Alvarez's tax proposal, Tabora (2018), president of a Catholic University, opined that while the tax proposal will not affect religious freedom, it threatens the sustainability of Catholic and other religious schools in the country. He urged all Catholic schools and supporters to oppose all new taxes on private education, especially Catholic non-profit, non-stock schools. Alvarez was later ousted as House Speaker and was replaced by former Philippine President Gloria Macapagal-Arroyo, a devout Catholic who maintains good relations with many bishops.

In addressing government leaders' "hateful speech" against the Catholic Church, the use of 'counterspeech' has been proposed to neutralize the impact of offensive discourse (Regidor 2017). It further identifies policy enforcement e.g., social media, etc. and education as meaningful antidotes to address hate speech. Such recommendations are consistent with higher education institution's vocation to promote "lifelong learning" (Yang et al. 2015) which includes responsible citizenship as an area of concern. As the conflict could induce fear and pessimism among students, university accompaniment provides students the confidence and fundamentals to express religious commitments without fear (Boys et al. 1995). Secondly, academic institutions can do best through conscientization (Freire 2007) to arouse young learner's imagination to honor the truth and engage with relevant social issues.

Outside the ambit of higher academic institutional involvement are untapped opportunities for families, parishes and basic education schools. A systematic response from these units provide potential resolutions to possible conflicts arising from changing Church-State relations. Actual engagements of Parishes come through educational initiatives to raise political consciousness and social responsibility through grassroots-based Basic Ecclesial Communities (BEC). The social encyclicals of the Church (Massaro 2016) provide comprehensive ideas covering the common good, solidarity, human rights, and dignity among others. Alongside this initiative, basic education schools can focus on processing children's awareness for possible mental stresses brought about by institutional conflicts.

\section{Conclusions}

Church-State relations in the Philippines have radically changed from its previous order in the Spanish colonial times to the present. From a "union" during the Spanish era, institutional relations are now guided by the principle of separation of Church and State. Common interpretations of this principle have been misguided, to the extent that religious institutions are expected to be absolutely 
detached from secular/public affairs. As such, "encroachments" on the political realm have often received accusations of violation of the principle of separation of Church and State. Such reaction draws from a strict separationist view of the principle. Going beyond the mutual respect usually accorded by the two institutions to each other, the recent conflict between the Catholic hierarchy and the Duterte government points to different ways of looking at the principle of separation not typically observed in other contexts.

While the formation of the Philippine secular state could be traced to the American colonial period, Philippine Church-State relations and jurisprudence were markedly different from the American tradition. Anti-clericalism never gained a strong foothold in the Philippines, much more deeply felt in its legal traditions. As the Philippine Supreme Court pointed out in Estrada vs. Escritor (2003), separationist interpretations were part of American jurisprudence on religion clauses but "the wellspring of Philippine jurisprudence on this subject is for the most part, benevolent neutrality which gives room for accommodation".

The present tension between President Duterte and ecclesiastical leaders could be perceived as a test on religion and democracy in the Philippines. Rather than a violation of the principle of separation of Church and State based on strict separationist and raw interpretations, the conflict represents the clash of interests and ideologies in a rapidly secularizing sociopolitical environment. As demonstrated by the two episodes discussed in this study, the institutional interests of the Catholic Church based on its social doctrines have come in conflict with those of the political interests of government leaderships. The latter's political interests in legislative and executive action (i.e., RH law, Duterte's drug war) were conditioned by prior commitments to the broader public, and not to the Catholic hierarchy alone. Moreover, the legislative and executive policies reflected secular and ideological beliefs of the dominant political coalition, however thin they may be, which contradicted Catholic Church beliefs on human life and dignity. The two presidents' conflict with the Catholic Church on these issues have not diminished their popularity and public approval ratings.

However, it could be argued that the clash of interests and ideologies, despite the pain and anguish it might have inflicted on either party, has not produced any significant impact on state policy toward religion. Certainly, there have been threats from some government leaders, such as taxing the church, but such threats are hollow in view of existing constitutional provisions that guarantee and support religion and religious freedom in the country. Religious participation in civil society is an integral part of Philippine democratic processes; church expressions of its moral positions in the public/political sphere is part of the religious freedom guaranteed by the constitution.

Author Contributions: The present study is the fruit of collaboration between the two authors. Both authors are involved in its re-conceptualization, design, analysis, writing, review and editing of the whole draft until its completion. The authors deeply appreciate the helpful suggestions and comments of the peer reviewers to further improve the articulation of the material.

Funding: This research received no external funding.

Conflicts of Interest: The authors declare no conflict of interest.

\section{References}

ABS-CBN News. 2016. CBCP to Voters: 'Reject Morally Reprehensible Bet'. Available online: https://news.abscbn.com/halalan2016/nation/05/01/16/cbcp-to-voters-reject-morally-reprehensible-bet (accessed on 3 February 2019).

ABS-CBN News. 2019. International Groups Press Duterte to End War vs. Human Rights Defenders. Available online: https: / news.abs-cbn.com/news/02/28/19/international-groups-press-duterte-to-end-war-vshuman-rights-defenders (accessed on 3 March 2019).

Association of Catholic University of the Philippines (ACUP). 1973. ACUP Primer. Available online: http: / / www.acup.org.ph/downloads/primer2019.pdf (accessed on 3 March 2019).

Aprieto, Pacifico. 1981. Book Publishing and Philippine Scholarship. Manila: Daily Star Publishing Co. 
Baring, Rito. 2011. Plurality in Unity: Challenges toward Religious Education in the Philippines. Religious Education 106: 459-75.

Baring, Rito. 2012. Challenges to Reproductive Health in the Philippines: Profiling the Attitudinal Sources of Conflict. Asia-Pacfic E-Journal of Health Social Science 1: 1-11.

Baring, Rito. 2018. Emerging Transitions in the Meaning of Religious Constructs: The Case of the Philippines. Religions 9: 387. [CrossRef]

Batalla, Eric Vincent, Michelle Sta Romana, and Karen Rodrigo. 2018. The judiciary under threat. In Routledge Handbook on the Contemporary Philippines. Edited by Mark Thompson and Eric Vincent Batalla. London and New York: Routledge, pp. 130-43.

Berger, Peter L. 1969. The Sacred Canopy. New York: Doubleday.

Boys, Mary, Sara Lee, and Dorothy Bass. 1995. Protestant, Catholic Jew: The Transformative Possibilities of Educating cross Religious Borders. Religious Education 90: 254-76. [CrossRef]

Buckley, David. 2013. Benevolent Secularism: The Emergence and Evolution of the Religious Politics of Democracy in Ireland, Senegal, and the Philippines. Ph.D. dissertation, Georgetown University, Washington, DC, USA.

Canceran, Delfo. 2016. Interrogating Secularism: The Case of the Filipino Experience. Journal of Asian Theology 30: 115-30.

Cayabyab, Marc Jayson. 2017. Alvarez Eyes Taxing Church-Run Schools. Inquirer.Net. March 6. Available online: https:/ / newsinfo.inquirer.net/877942/alvarez-eyes-taxing-church-run-schools (accessed on 18 February 2019).

Catholic Educational Association of the Philippines (CEAP). 2014. Available online: https:/ /www.ceap.org.ph/ (accessed on 2 February 2019).

Chanco, Boo. 2016. Will Duterte dare to tax the Church? Philippine Star, July 4. Available online: https:/ / www. philstar.com/business/2016/07/04/1599267/will-duterte-dare-tax-church (accessed on 16 February 2019).

Esmaquel, Paterno. 2012. Catholics clash over controversial RH bill. Rappler.com. August 4. Available online: https:/ / www.rappler.com/nation/9795-catholics-clash-over-controversial-rh-bill (accessed on 26 February 2019).

Estrada, Joseph Noel. 2017. It Isn't about the Salary, Your Honor! March 14. Available online: http://www. manilatimes.net/isnt-salary-honor/317086/ (accessed on 11 February 2018).

Estrada vs. Escritor. 2003. A.M. No. P-02-1651. August 4. Available online: http://sc.judiciary.gov.ph/ jurisprudence/2003/aug2003/am_p_02_1651.htm (accessed on 25 February 2019).

Estrada vs. Escritor. 2006. A.M. No. P-02-1651. June 22. Available online: http://sc.judiciary.gov.ph/ jurisprudence/2006/june2006/A.M.\%20No.\%20P-02-1651.htm (accessed on 25 February 2019).

Freire, Paolo. 2007. Pedagogy of the Oppressed. New York: Continuum.

Gill, Anthony. 2007. The Origins of Religious Liberty. Cambridge and New York: Cambridge University Press.

Griffin, Leslie C. 2015. The Catholic Bishops vs. the Contraceptive Mandate. Religions 6: 1411-32. [CrossRef]

Imbong, James, Lovely-Ann Imbong, Lucia Carlos Imbong, and Bernadette Carlos Imbong vs. Ochoa, Paquito Jr., Florencio Abad, Enrique Ona, Armin Luistro, Manuel Roxas II. et al. 2014. G.R. No. 204819. April 8. Available online: http:/ /sc.judiciary.gov.ph/jurisprudence/2014/april2014/204819.pdf (accessed on 25 February 2019).

Inkeles, Alex, and David Horton Smith. 1976. Becoming Modern: Individual Change in Six Developing Countries. Cambridge: Harvard University Press.

Inquirer.net. 2018. Tax Exemptions for Religious Groups May Soon End. Philippine Daily Inquirer, April 10. Available online: https://newsinfo.inquirer.net/981279/tax-exemptions-for-religious-groups-may-soonend-alvarez (accessed on 18 February 2019).

Kapunan, Rod. 2018. Tax All Church Properties. Manila Times, June 2. Available online: http:/ / www.manilastandard.net/opinion/columns/backbencher-by-rod-kapunan/267084/tax-allchurch-properties.html (accessed on 18 February 2019).

Kuru, Ahmet. 2009. Secularism and State Policies toward Religion. Cambridge and New York: Cambridge University Press. Lagman, Oscar. 2017. Church Lost Its Influence during the Arroyo Presidency. Inquirer.net, January 23. Available online: https://opinion.inquirer.net/101048/church-lost-influence-arroyo-presidency. (accessed on 24 February 2019).

Lee, Romeo, Rito Baring, Madelene Sta Maria, and Stephen Reysen. 2017. Attitude towards Technology, Social Media Usage and Grade-Point Average as Predictors of Global Citizenship Identification in Filipino University Students. International Journal of Psychology 52: 213-19. [CrossRef] [PubMed] 
Lieberman, Robert. 2002. Ideas, Institutions, and Political Order: Explaining Political Change. The American Political Science Review 96: 697-712. [CrossRef]

Manila Standard. 2016. Duterte and the Bishops. Editorial. May 23. Available online: http://manilastandard.net/ opinion/editorial/206271/duterte-and-the-bishops.html (accessed on 24 February 2019).

Massaro, Thomas. 2016. Living Justice: Catholic Social Teaching in Action. London: Rowman \& Littlefield.

Norris, Pippa, and Ronald Inglehart. 2004. Sacred and Secular: Religion and Politics Worldwide. Cambridge: Cambridge University Press.

Official Gazette. 2012. Benigno S. Aquino III, Third State of the Nation. July 23. Available online: https: / www.officialgazette.gov.ph/2012/07/23/benigno-s-aquino-iii-third-state-of-the-nationaddress-july-23-2012/ (accessed on 3 March 2019).

Pangalangan, Raul. 2015. National Report for the Philippines. In Religion and the Secular State: National Reports. Edited by Javier Martinez Torron and William Cole Durham Jr. Madrid: Universidad Complutense, pp. 559-71.

Philpott, Daniel. 2007. Explaining the Political Ambivalence of Religion. The American Political Science Review 101: 505-25. [CrossRef]

Pollack, Detlef. 2015. Varieties of Secularization Theories and their Indispensable Core. The Germanic Review: Literature, Culture, Theory 90: 60-79. [CrossRef]

Regidor, Anna. 2017. Digong vs. the Catholic Church. UPdate Diliman. Available online: https://upd.edu.ph/ digong-vs-the-catholic-church/ (accessed on 3 March 2019).

Tabora, Joel. 2018. Taxation for Catholic Schools? [Blog Post], April 24. Available online: https://taborasj. wordpress.com/2018/04/24/taxation-for-catholic-schools / (accessed on 18 February 2019).

The Republic of the Philippines. 1987. The 1987 Constitution of the Philippines. Available online: https: / / www.officialgazette.gov.ph/constitutions/1987-constitution/ (accessed on 1 February 2019).

Thompson, Mark. 2016. Bloodied Democracy: Duterte and the Death of Liberal Reformism in the Philippines. Journal of Current Southeast Asian Affairs 35: 39-68. [CrossRef]

Thompson, Mark. 2018. The Presidency: A Relational Approach. In Routledge Handbook on the Contemporary Philippines. Edited by Mark Thompson and Eric Vincent Batalla. London and New York: Routledge, pp. 118-29.

Von der Mehden, Fred R. 1986. Religion and Modernization in Southeast Asia. Syracuse: Syracuse University Press. Yang, Jin, Chripa Schneller, and Stephen Roche, eds. 2015. The Role of Higher Education in Promoting Lifelong Learning. Hamburg: UNESCO Institute for Lifelong Learning.

(C) 2019 by the authors. Licensee MDPI, Basel, Switzerland. This article is an open access article distributed under the terms and conditions of the Creative Commons Attribution (CC BY) license (http://creativecommons.org/licenses/by/4.0/). 